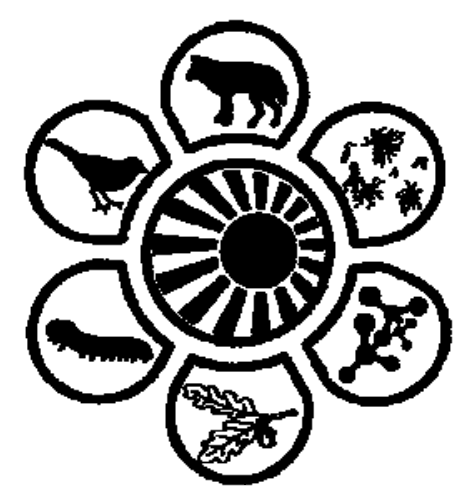

Вісник Дніпропетровського університету. Біологія, екологія.

Vìsnik Dnìpropetrovs'kogo unìversitetu. Seriâ Bìologiâ, ekologiâ

Visnyk of Dnipropetrovsk University. Biology, ecology.

Vìsn. Dnìpropetr. Unìv. Ser. Bìol. Ekol. 2015. 23(2), 116-123.

doi: $10.15421 / 011517$

ISSN 2310-0842 print

ISSN 2312-301X online

www.ecology.dp.ua

УДК 574.5(477.87)

\title{
Сучасний стан водних ресурсів Закарпаття
}

\author{
В.І. Ніколайчук ${ }^{1}$, М.М. Вакерич ${ }^{1}$, Ю.М. Шпонтак ${ }^{2}$, М.К. Карпюк ${ }^{2}$ \\ ${ }^{I}$ Ужсгородський національний університет, Ужсгород, Україна \\ ${ }^{2}$ Департамент екології та природних ресурсів Закарпатської обласної державної адміністрації, Ужгород, Украӥна
}

Закарпатська область розташована в центрі Європи, межує з чотирма Центральноєвропейськими країнами (Польщею, Словаччиною, Угорщиною та Румунією) та двома областями України (Львівською та Івано-Франківською). Закарпаття - один із найкраще забезпечених водними ресурсами регіонів України. Територія області перерізана густою мережею річок. Усього на території області протікає 9429 річок, сумарна довжина яких становить 19866 км. Із них ріки Тиса, Боржава, Латориця та Уж мають довжину понад 100 км кожна. Централізованими водозаборами питних підземних вод забезпечені практично 25 міст і селищ міського типу області. У сільських населених пунктах централізоване водопостачання практично відсутнє, воно здійснюється переважно за рахунок побутових колодязів чи свердловин. Прогнозні ресурси питних підземних вод в області становлять 1,109 млн м²/добу. Використання свіжої води за 2014 рік на одного мешканця склало 23,769 м³, що на $15 \%$ менше аналогічного показника 2009 року. Основні забруднювачі поверхневих вод - об'єкти житлово-комунальних підприємств області. За більшістю показників загальносанітарного аналізу та специфічних показників якість води відповідає санітарним правилам і нормам. Із загальної кількості водопроводів 19,0\% не відповідають санітарним вимогам: через відсутність зон санітарної охорони - 14,2\%, через відсутність необхідного комплексу очисних споруд - 1,9\%, через відсутність знезаражувальних установок $-7,6 \%$. Можливим шляхом запобігання виснаженню водних об'єктів є профілактичні водоохоронні заходи, спрямовані на запобігання або обмеження забруднення, засмічення та виснаження вод, а також екологічна просвітницька робота серед населення.

Ключові слова: річки Закарпаття; забруднення; виснаження; стічні води

\section{The current state of water resources of Transcarpathia}

\author{
V.I. Nikolaichuk ${ }^{1}$, M.M. Vakerich ${ }^{1}$, J.M. Shpontak ${ }^{2}$, M.K. Karpu'k ${ }^{2}$ \\ ${ }^{1}$ Uzhgorod National University, Uzhgorod, Ukraine \\ ${ }^{2}$ Department of Ecology and Natural Resources of Transcarpathian Government, Uzhgorod, Ukraine
}

Throughout their existence, humans use the water of rivers, lakes and underground sources not only for water supply but also for dumping of polluted waters and wastes into it. Significant development of urbanization, concentration of urban industrial enterprises, transport, increase in mining, expansion of drainage and irrigation reclamation, plowing of the river channels, creating a large number of landfills resulted in significant, and in some regions critical, depletion and contamination of the surface and ground waters. Because of this disastrous situation, the society is getting more and more concerned about the state of the environment. The public became increasingly interested in the state of the soil cover, air, water resources, and biotic diversity. Transcarpathian region (Zakarpattya) is situated in the heart of Europe, bordered by four Central European countries (Poland, Slovakia, Hungary and Romania) and two regions of Ukraine (Lviv and Ivano-Frankivsk regions). Transcarpathian region (Zakarpattya) is one of the richest regions of Ukraine in terms of water resources. The territory is permeated by the dense network of rivers. There are in total 9,429 rivers of 19,866 km length flowing in the region. Among them, the rivers Tysa, Borzhava, Latoryca, Uzh have the length of over $100 \mathrm{~km}$ each. 25 cities and urban settlements of the area are substantially provided with the centralized water intake of underground drinking water. The rural areas have virtually no centralized water supply; mainly, it is carried out due to domestic wells or water boreholes. Predicted resources of underground drinking waters in the region are equal to $1,109,300 \mathrm{~m}^{3} /$ day. The use of fresh water in 2014 per capita amounted to $23,769 \mathrm{~m}^{3}, 15 \%$ less than in 2009 . The main pollutants of surface

Ужгородський начіональний університет, вул. Волошина, 32, Ужгород, 88000, Украӥна Uzhgorod National University, Voloshyn Str., 32, Uzhgorod, 88000, Ukraine

Департамент екології та природних ресурсів Закарпатської обласної державної адміністраиії, вул. Швабська, 14, Ужгород, 88018 Department of Ecology and Natural Resources of Transcarpathian Government, Shvabska Str., 14, Uzhgorod, 88018, Ukraine Tel.: +38-050-955-44-87.E-mail: vakerich@yandex.ru, central@ecozakarpat.gov.ua 
water bodies are the facilities of utility companies in the region. Analysis of studies of surface water quality in Transcarpathian region in 2014 shows that water quality meets the sanitary rules and regulations by the most of indicators of general health and specific indices. $19.0 \%$ of total water supply systems fail to meet the sanitary norms and regulations, in particular: $14.2 \%$ for the lack of sanitary protection zones; $1.9 \%$ because of unavailability of the necessary integrated treatment facilities, and $7.6 \%$ by the reason of absence of disinfecting plants. Possible ways of avoiding the depletion of water bodies are preventive water protection measures aimed at preventing or limiting pollution, water contamination and depletion; besides, it is necessary to educate people explaning them the current state and possible consequences of thoughtless water consumption.

Keywords: Transcarpathian rivers; pollution; depletion; waste water

\section{Вступ}

Упродовж свого існування людство використовує воду річок, озер і підземних джерел не тільки для водопостачання, а i для скидання в них забруднених вод i відходів виробництва. До початку XX ст. це не викликало особливої стурбованості. Сонячна радіація, кисень, фізико-хімічні процеси, живі організми забезпечували самоочищення водних об'єктів. Ще 50-70 років тому забруднені води міських поселень нерідко скидалися без очищення в річки. Через 15-20 км вони самоочищалися до такого рівня, що їх знову забирали на водопостачання інших міст. Значний розвиток урбанізації, концентрація у містах промислових підприємств, транспорту, збільшення обсягів видобутку корисних копалин, розширення масштабів осушувальних і зрошувальних територій, розорювання земель до річкових русел, створення великої кількості сміттєзвалищ зумовили значне, а в окремих регіонах критичне виснаження та забруднення поверхневих і підземних вод (Klimas, 1995; Yakovlev et al., 2002; Klepov, 2007; Prikhod'ko, 2007; Chaithanya et al., 2013; Di Nardo et al., 2013; Walcher and Bormann, 2015). Забрудненими виявилися не лише малі річки та озера, а й великі річкові системи, підземні водоносні горизонти. В освоєних регіонах світу не залишилося великих річкових і озерних систем із близьким до натурального гідрологічним режимом і хімічним складом вод (Bobyliov et al., 2014). Через знесення річками, аварії на водному транспорті та бурових платформах, поховання відходів у водній товщі та дні нині значно забруднені води окремих морів і всього Світового океанy (Nikolajchuk, 1998, 2004, 2007; Nikolajchuk et al., 1999, 2001; Nikolajchuk and Grabovskyi, 2000; Kovalchuk et al., 2001; Nikolajchuk and Potish, 2001).

Наслідком необдуманого впливу стало погіршення стану природних екосистем, що піддаються навантаженню, а відтак, людина як частина цих екосистем теж зазнає негативного впливу від власної діяльності (Napier and Tucker, 2001; Korfali and Jurdi, 2009; Litskas et al., 2010).

Прикладом забруднення, що мав місце протягом останнього часу на території Закарпаття, є прорив дамб відстійника гірничодобувного підприємства у БаяБорша (Румунія), внаслідок чого води, забруднені важкими металами, потрапили з річки Вішеу у Тису. За даними держуправління екобезпеки Закарпатської області, після другого прориву забрудненість перевищила допустимі норми по $\mathrm{Cu}$ у 200 разів, по $\mathrm{Zn}-10, \mathrm{~Pb}-14$, $\mathrm{Mg}-60, \mathrm{Fe}-620$ разів. Важкі метали не лише забруднили воду, а й осіли у грунтах, на яких місцеве населення вирощує сільськогосподарську продукцію. Використання таких забруднених важкими металами грунтів для вирощування сільськогосподарської продукції неприпустиме.
У зв'язку з таким катастрофічним станом останніми роками суспільство все більше турбується про стан довкілля. Соціум нарешті зрозумів, що довкілля $є$ не абстрактним поняттям, це - місце існування людини, середовище, в якому вона виховує своїх дітей. Громадськість почала активно цікавитися станом грунтового покриву, атмосферного повітря, водних ресурсів, біологічного різноманіття.

\section{Фізико-географічна характеристика Закарпатської області}

Закарпатська область розташована в центрі Європи, межує 3 чотирма Центральноєвропейськими країнами (Польщею, Словаччиною, Угорщиною та Румунією) та двома областями України (Львівською та Івано-Франківською), займає площу 12,8 тис. км² (рис. 1). Геодезичний знак географічного центру Свропи розташований поблизу с. Ділове Рахівського району. Близько 2/3 території Закарпаття - гірська місцевість. Область розташована на південно-західних схилах Українських Карпат і на прилеглій до них Закарпатській низовині, яка $\epsilon$ частиною Середньо-Дунайської низовини. Гірська частина області включає три групи асиметричних хребтів із розлогими південно-західними схилами, прорізаними численними долинами гірських річок. У центрі - ланцюг Полонинських гір із плоскими вершинами - полонинами, вкритими гірськими луками, які використовуються як пасовища (це полонини: Рівна, Красна, Боржава, Свидовець тощо). Найвища гора Українських Карпат Говерла (2 061 м над рівнем моря) (Stojko, 2000, 2008).

Територія області є водозбором р.Тиса, яка є притокою р. Дунай. Усі річки та потічки, які формуються по долинах і ущелинах гір, а їх на Закарпатті понад 9 тисяч, належать до басейну р. Тиса, є іiї притоками. Найбільші 3 них - це річки Тересва, Теребля, Ріка, Боржава, Латориця та Уж. Дві останні впадають у р. Бодрог на території Словаччини, яка в подальшому впадає у р. Тиса. Водний режим річок дуже мінливий. Він залежить від погоднокліматичних умов і тісно пов'язаний зі станом лісів Українських Карпат (Zastavecka and Zastaveckyi, 1996; Felbaba-Klushyna, 2009; Felbaba-Klushyna and Nikolajchuk, 2010).

Закарпаття багате на різноманітні корисні копалини, що мають промислове значення: кольорові, рідкісні та дорогоцінні метали (золото, срібло, ртуть, германій, цинк тощо), неметали (барит, цеоліт, бентоніт, доломіт, алуніт), сіль, вугілля, газ, будівельні матеріали (мармур, базальт, андезит, керамзит, перліт тощо), мінеральні та термальні води. Формування більшості родовищ корисних копалин пов'язане з останнім етапом розвитку Карпат. Однак формування кристалічних сланців, мармурів, кварцитів тощо, які розміщені на великих глибинах $\mathrm{i}$ 
тільки в Мармороському кристалічному масиві виходять на поверхню (Рахівський район), відбулося на самому початку утворення гір (230-240 млн років тому) (Gerenchuk, 1981).

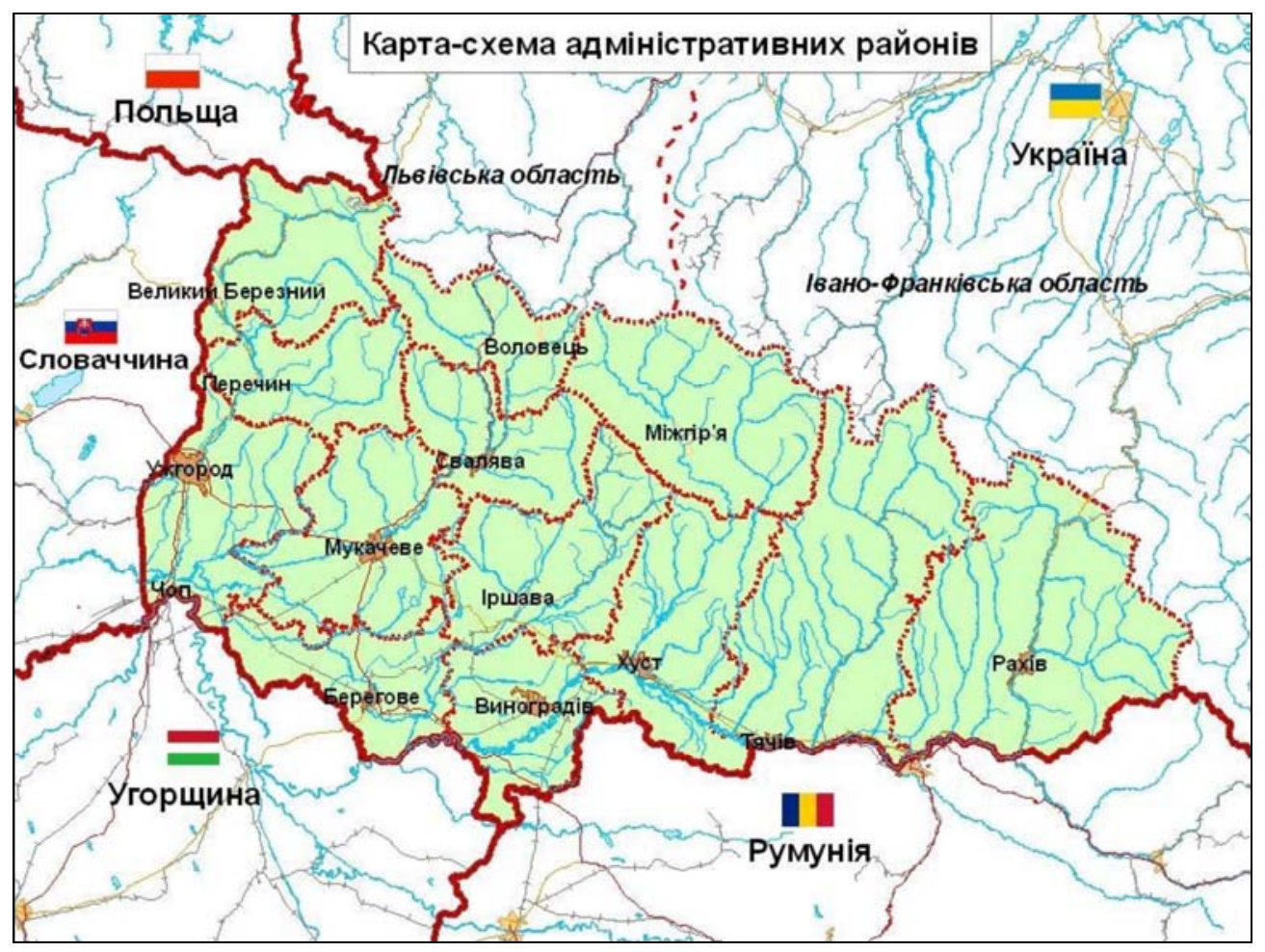

Рис. 1. Карта-схема Закарпатської області

Клімат Закарпаття помірно континентальний із достатнім і надлишковим зволоженням, нестійкою весною, не дуже спекотним літом, теплою осінню та м'якою зимою. Середньорічна швидкість вітру у різних місцях становить 1,2-2,4 м/с, тоді як максимальна швидкість, зареєстрована в районі міст Хуст і Міжгір'я, становить 40 м/с. Середньомісячна багаторічна температура січня у горах становить $-7,8^{\circ} \mathrm{C}$, тоді як у низині (м. Ужгород) тільки $-3,1{ }^{\circ} \mathrm{C}$, а влітку $-+11 \ldots+14{ }^{\circ} \mathrm{C}$ у високогір'ї та $+20 \ldots+21{ }^{\circ} \mathrm{C}$ на низині. Зі зростанням висоти місцеположення території збільшується також кількість опадів. Середньорічні опади в низинній зоні становлять 600-800 мм, а в горах - 1000-1 500 мм (Vasylevskyi, 1973; Pop, 2002).

\section{Водно-ресурсний потенціал Закарпатської області}

Закарпатська область - один із найкраще забезпечених водними ресурсами регіонів України. Водні ресурси тут формуються за рахунок поверхневого стоку річок басейну ріки Тиса: місцевого річкового стоку, що утворюється в межах області, транзитного річкового стоку, що утворюється на території Румунської, Угорської та Словацької Республік, а також експлуатаційних запасів підземних вод (Mishhenko, 2009). Річки Закарпаття в географічному плані розміщені та належать до басейну однієї з найбільших приток Дунаю - Тиси, яка є основною водною артерією області. Всі річки беруть свій початок у високогірній частині Карпат (Semal, 2014).

Територія області перерізана густою мережею рік. Середня густина річкової сітки $-1,7$ км/км². Усього на території області протікає 9429 річок, сумарна довжина яких становить 19866 км. Загальна довжина 155 річок, кожна $з$ яких довша 10 км, становить 3,43 тис. км. Із них ріки Тиса, Боржава, Латориця та Уж мають довжину понад 100 км кожна. Кількість малих річок (довжиною до 10 км) становить 9277, що відповідає 79\% усіх водотоків. Їх загальна довжина 16248 км.

Загальна протяжність ріки Тиса - 967 км, із них у межах України - 262 км. На території області вона приймає праві притоки: річки Косовська (41 км), Тересва (56 км), Теребля (91 км), Ріка (92 км), Боржава (106 км). Довжина р. Латориця 191 км (у межах області 144 км), річки Уж - 133 км (у межах області - 107 км).

В області нараховується 9 водосховищ і 59 ставків. Загальний об'єм усіх штучних водосховищ 60,5 млн м³, площа водного дзеркала становить 1,56 тис. га. Найбільшим є Синевирське озеро площею близько 7 га, середньою глибиною 15-16 м. Воно розташоване на висоті 989 м над рівнем моря.

Прогнозні ресурси питних підземних вод в області, за даними Закарпатської геологорозвідувальної експедиції, становлять 1,109 млн м³/добу. У цілому цих ресурсів достатньо для задоволення потреб населення у питній воді, але вони поширені дуже нерівномірно. Інформація про прогнозні ресурси підземних вод, за даними Закарпатського геолого-гідрогеологічного центру Львівської геологорозвідувальної експедиції ДП «Західукргеологія» НАК «Надра України», наведена у таблиці 1.

У рівнинній частині області ресурси підземних вод значно перевищують обсяги їх можливого використання. У гірській частині Закарпаття, особливо на територіях із водонепроникними флішовими породами, ресурси питних підземних вод незначні, до 50$100 \mathrm{~m}^{3} /$ добу. У зв'язку з цим перспективними для 
централізованого забезпечення населення якісною водою $є$ гірські потічки на залісених ділянках за межами населених пунктів.

Таблиия 1

Прогнозні ресурси підземних вод Закарпатської області

\begin{tabular}{|c|c|c|}
\hline $\begin{array}{c}\text { Адміністративно- } \\
\text { територіальний } \\
\text { та басейновий розріз }\end{array}$ & $\begin{array}{c}\text { Прогнозні } \\
\text { ресурси, } \\
\text { млн м³/добу }\end{array}$ & $\begin{array}{c}\text { Кількість } \\
\text { свердловин, шт. }\end{array}$ \\
\hline Берегівський район & 0,478 & 47 \\
\hline Великоберезнянський район & 0,003 & 16 \\
\hline Виноградівський район & 0,271 & 26 \\
\hline Воловецький район & - & - \\
\hline Іршавський район & 0,012 & 32 \\
\hline Міжгірський район & - & 5 \\
\hline Мукачівський район & 0,085 & 190 \\
\hline Перечинський район & 0,006 & 18 \\
\hline Рахівський район & 0,011 & 20 \\
\hline Свалявський район & - & 13 \\
\hline Тячівський район & 0,059 & 26 \\
\hline Ужгородський район & 0,154 & 139 \\
\hline Хустський район & 0,027 & 48 \\
\hline у тому числі: для м. Ужгород & - & 44 \\
\hline для м. Берегове & - & 24 \\
\hline для м. Мукачеве & - & 130 \\
\hline для м. Хуст & - & 34 \\
\hline для м. Чоп & - & 16 \\
\hline Разом & 1,109 & 580 \\
\hline
\end{tabular}

Примітка: «-»- аналіз не проводився.

Централізованими водозаборами питних підземних вод забезпечені 25 міст і селищ міського типу області. У сільських населених пунктах централізоване водопостачання практично відсутнє. Їх водозабезпечення здійснюється переважно за рахунок побутових колодязів. При локальному водозабезпеченні окремих адміністративних, соціальних, промислових, сільськогосподарських та інших об'єктів використовуються поодинокі свердловини. Усього в області в різні роки, за офіційною інформацією, пробурено близько 1300 експлуатаційних (на питну воду) свердловин. Середній багаторічний стік, який формується в межах області, становить близько 7040 млн м³/рік. Разом із транзитним, що надходить із суміжних територій, поверхневий стік річок області становить 13440 млн м³/рік (Semal, 2015).

\section{Основні показники водокористування} та водовідведення у Закарпатській області

У 2014 році основні водокористувачі області (451 суб'єкт) забрали із природних водних об'єктів 38,24 млн м ${ }^{3}$ води (що на $15 \%$ менше, ніж у 2009 р.) та скинули 32,67 млн м ${ }^{3}$ зворотних вод (на 30\% менше, ніж у 2009 р.). За останні роки спостерігається також тенденція до зменшення обсягів використання свіжої води. У 2014 р. показник використання свіжої води по всіх галузях становив 29,94 млн м³ , що на 15\% менше, ніж у 2009 році $\left(35,05\right.$ млн м $\left.{ }^{3}\right)$ та у 4,7 раза менше 1990 року (143,5 млн м³) (рис. 2). Найбільше використано води на побутово-питні потреби - 13,94 млн м³. На сільськогосподарські потреби використано 1,55 млн м ${ }^{3}$ (що майже утричі менше, ніж у 2009 р.), на виробничі потреби - 4,04 млн м ${ }^{3}$ (що на 23\% менше показника 2009 р.).

Використання свіжої води за 2014 рік на одного мешканця склало $23,77 \mathrm{~m}^{3}$, що на $15 \%$ менше аналогічного показника 2009 року $\left(28,16\right.$ м $\left.^{3}\right)$. Значними і неприпустимими, за умови сучасного водного дефіциту, є втрати води під час транспортування, що у 2014 році становили 8,22 млн м ${ }^{3}$, а це складає понад $27 \%$ загальної кількості використаної свіжої води. Великий обсяг втрат води зумовлений застарілими мережами водопостачання, які потребують невідкладного ремонту та переоснащення.

Показники водовідведення порівняно 3 попередніми роками також зменшилися. Загальна сума скинутих зворотних вод у 2014 році становила 32,67 млн м ${ }^{3}$, що майже на $30 \%$ менше показника 2009 року $\left(46,24\right.$ млн м $\left.{ }^{3}\right)$ і на понад 45\% менше, ніж у 2000 році $\left(58,82\right.$ млн м $\left.{ }^{3}\right)$. Із загальної кількості скидів 2014 року 95\% (31,04 млн м $\left.{ }^{3}\right)$ скинуто у поверхневі водні об'єкти, з яких 89\% (27,65 млн м³) були очищені на спорудах біологічного чи механічного очищення. У звітній доповіді Департаменту екології та природних ресурсів Закарпатської ОДА «Про стан навколишнього природного середовища Закарпатської області» (2013) наведено інформацію про те, що найпотужніші споживачі води - це підприємства житлово-комунального господарства області (65\% загального використання води по області) та сільського господарства (30\% використання води). У галузі сільського господарства області водні ресурси використовуються у двох основних напрямках: сільськогосподарське водопостачання та рибне господарство.

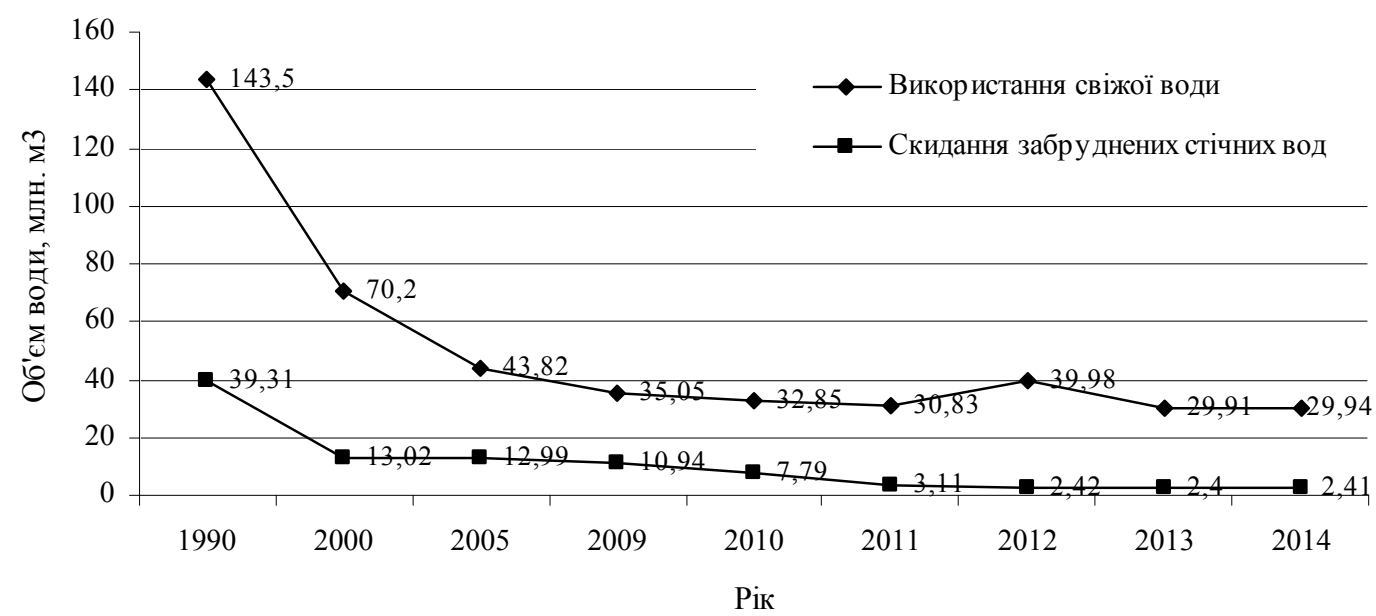

Рис. 2. Динаміка водокористування та водовідведення у Закарпатській області 
Найбільші забруднювачі поверхневих вод - об'єкти житлово-комунальних підприємств області (рис. 3), які у 2013 році скинули 2,36 млн м ${ }^{3}$ забруднених стічних вод (98,7\% скиду забруднених стоків області). У 2014 році даний показник збільшився на майже 9\% і становив 2,69 млн м ${ }^{3}$ (Semal, 2015).

Беручи до уваги динаміку показників скинутих забруднювальних речовин зі зворотними водами, згідно 3 даними статистичної звітності у 2014 році даний показник становив 17,656 тис. тонн, що майже на 2\% та 4\% менше відповідних показників 2013 та 2012 рр.

На виконання обласної програми «Питна вода Закарпаття на 2012-2020 роки» (затверджена 08.06.2012 р. № 473) аналіз стану поверхневих вод області виконано на основі гідрохімічних та гідрофізичних показників, наданих Державною екологічною інспекцією у Закарпатській області та Басейновим управлінням водних ресурсів p. Тиса, а також за санітарно-хімічними показниками якості відкритих водойм I та II категорії (у місцях проживан- ня та відпочинку населення), наданих обласною санітарно-епідеміологічною станцією. Спостереження за гідрофізичними та гідрохімічними показниками якості поверхневих вод регіону велися Держекоінспекцією у Закарпатській області на 11 створах моніторингу (табл. 2).

\section{Оцінка якості вод за гідрохімічними показниками}

Аналіз досліджень якості поверхневих вод Закарпатської області за 2014 рік показав, що за більшістю показників загальносанітарного аналізу та специфічних показників якість води відповідає санітарним правилам і нормам Сан-ПіН 4630-88: запах, кольоровість, розчинений кисень, водневий показник $(\mathrm{pH})$, азот амонійний, нітрити, нітрати, фосфати, загальний фосфор, хімічне споживання кисню, сухий залишок, сульфати, хлориди, нафтопродукти, феноли, АПАР, хром, мідь, цинк, нікель, кадмій, свинець.

Табличя 2

Середньорічні концентрації речовин у міжнародних контрольних створах водних об’'ктів регіону за 2014 рік (за даними Державної екологічної інспекції у Закарпатській області)

\begin{tabular}{|c|c|c|c|c|c|c|c|c|c|c|c|c|c|c|c|c|c|c|c|}
\hline Розта & 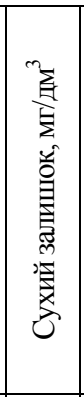 & 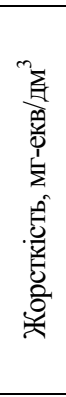 & 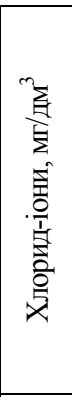 & 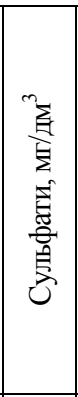 & 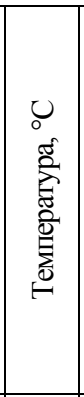 & 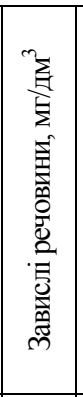 & 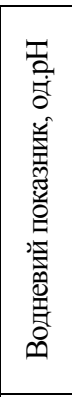 & 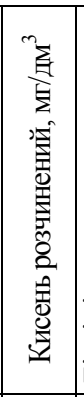 & 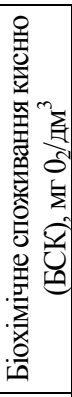 & 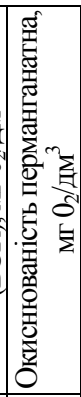 & 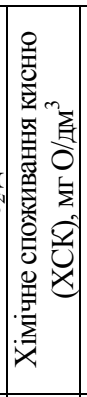 & 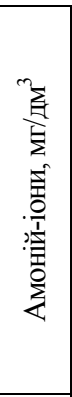 & 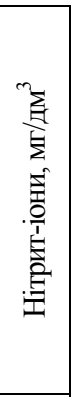 & 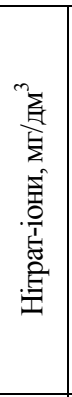 & 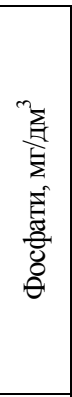 & 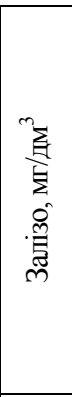 & 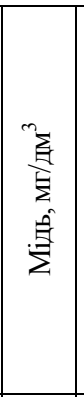 & 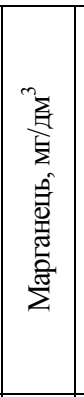 & 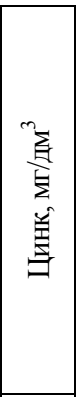 \\
\hline \begin{tabular}{|l|} 
p. Тиса, с. Ділове, вище \\
впадіння р. Вішеу \\
\end{tabular} & 146,7 & 2,30 & 9,02 & 15,38 & 11,80 & 10,00 & 7,73 & 10,60 & 2,12 & 2,70 & 7,68 & 0,10 & 0,02 & 1,61 & 0,03 & 0,18 & 0,002 & 0,018 & c \\
\hline \begin{tabular}{|l|} 
p. Тиса, с. Луг, нижче \\
впадіння р. Вішеу
\end{tabular} & 152,3 & 2,25 & 10,48 & 16,71 & 11,89 & 11,17 & 7,57 & 10,51 & 2,24 & 3,03 & 8,17 & 0,12 & 0,02 & 1,74 & 0,04 & 0,20 & 0,002 & 0,026 & 0,0 \\
\hline $\begin{array}{l}\text { p. Тиса, м. Тячів, кор- } \\
\text { дон Україна - Румунія }\end{array}$ & 181,9 & 2,45 & 16,21 & 23,41 & 13,15 & 14,17 & 7,82 & 10,50 & 2,58 & 3,57 & 9,78 & 0,16 & 0,03 & 2,23 & 0,06 & 0,20 & 0,003 & 0,021 & 0,0 \\
\hline $\begin{array}{l}\text { p. Тиса, } \\
\text { смт. Солотвине }\end{array}$ & 178,3 & 2,25 & 17,45 & 21,34 & 12,38 & 12,08 & 7,79 & 10,45 & 2,34 & 3,22 & 8,09 & 0,11 & 0,02 & 1,96 & 0,04 & 0,20 & 0,002 & 0,018 & 0,0 \\
\hline \begin{tabular}{|l|} 
p. Тиса, смт. Вілок, \\
1 км нижче селища, на \\
кордоні з Угорщиною \\
\end{tabular} & 156,2 & 2,20 & 12,28 & 16,34 & 12,66 & 12,58 & 7,85 & 10,52 & 2,15 & 3,07 & 7,45 & 0,09 & 0,02 & 2,26 & 0,04 & 0,15 & 0,012 & 0,017 & 0,0 \\
\hline $\begin{array}{l}\text { p. Тиса, м. Чоп, } 2 \text { км } \\
\text { нижче міста на кор- } \\
\text { доні з Угорщиною } \\
\end{array}$ & 233,2 & 2,30 & 19,61 & 24,65 & 14,61 & 16,50 & 7,92 & $|10,67|$ & 2,56 & 4,56 & $|10,51|$ & 0,15 & 0,03 & 2,58 & 0,05 & 0,21 & $0,016 \mid$ & 0,035 & 0,0 \\
\hline р. Боржава, с. Бене & 177,5 & 30 & 5,30 & 21,63 & 13,08 & 17,75 & 7,81 & 9,79 & 2,66 & 4,05 & 9,08 & 0,17 & 0,04 & 2,55 & 0,07 & 0,27 & 0,011 & 0,025 & 0,01 \\
\hline $\begin{array}{l}\text { p. Уж, с. Сторожниця, } \\
1 \text { км нижче села, } \\
\text { кордон Україна-Сло- } \\
\text { ваччина }\end{array}$ & 189,8 & - & 12,21 & 17,61 & 13,43 & 13,83 & 7,97 & 10,25 & 2,37 & 3,87 & 10,65 & 0,20 & 0,04 & 2,77 & 0,05 & 0,19 & 0,010 & 0,020 & 0,0 \\
\hline $\begin{array}{l}\text { p. Улічка, смт. В. Бе- } \\
\text { резний, кордон } \\
\text { Україна - Словаччи- } \\
\text { на, гирло річки }\end{array}$ & 166,3 & - & 10,15 & 13,13 & 14,03 & 9,75 & 8,12 & 11,03 & 2,28 & 3,45 & 9,70 & 0,14 & 0,02 & 1,73 & 0,04 & 0,15 & 0,005 & 0,013 & 0,0 \\
\hline $\begin{array}{l}\text { p. Убля, смт. М. Бе- } \\
\text { резний, кордон } \\
\text { Україна - Словаччи- } \\
\text { на, гирло річки } \\
\end{array}$ & 236,7 & - & 14,67 & 15,27 & 12,73 & 12,67 & 7,98 & 11,00 & 2,45 & 4,60 & 10,23 & 0,25 & 0,03 & 2,52 & 0,04 & 0,22 & 0,002 & 0,014 & 0,00 \\
\hline \begin{tabular}{|l|} 
p. Латориця, с. Страж, \\
на кордоні Україна - \\
Словаччина \\
\end{tabular} & 189,1 & - & 12,38 & 17,30 & 13,60 & 16,25 & 7,75 & 9,86 & 2,53 & 4,41 & 10,34 & 0,21 & 0,05 & 2,84 & 0,08 & 0,21 & 0,011 & 0,028 & 0,0 \\
\hline
\end{tabular}




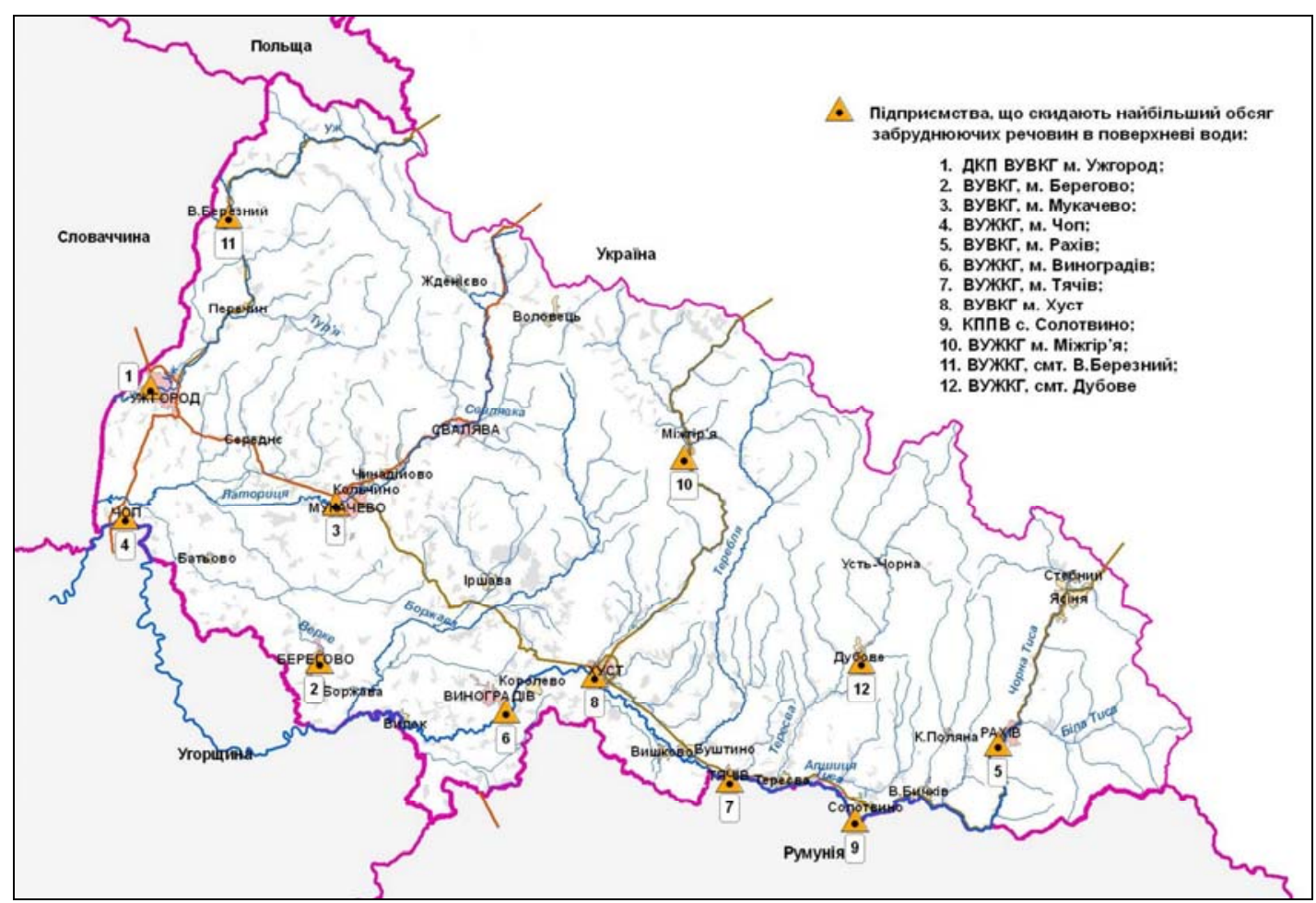

Рис. 3. Основні забруднювачі водних об'сктів у Закарпатській області

У деяких пунктах спостереження у 2014 р. порівняно 3 попередніми роками спостерігалось незначне поліпшення якості води за біохімічним споживанням кисню (БСКП). Гранично допустима концентрація (ГДК) для БСКп складає 3,0 мг $\mathrm{O}_{2} /$ дм$^{3}$. Специфічні показники не перевищували фонових значень. Вміст важких металів не перевищував ГДК. Аварійні ситуації не зафіксовані. Тенденцій щодо погіршення якості води не спостерігається. Для каналів меліоративних систем області характерний високий вміст заліза та марганцю.

Гамма-спектрометричні вимірювання поверхневих вод на вміст радіоцезію-137 в Закарпатській області здійснює Басейнове управління водних ресурсів річки Тиса на п’яти створах спостереження. За результатами радіометричних вимірювань проб води, питома активність радіоцезію-137 у створах спостережень річок області значно нижча за допустимі рівні (Semal, 2015).

\section{Якість питної води та її вплив на здоров'я населення}

Нагляд за дотриманням санітарного законодавства на об'єктах, що здійснюють забезпечення населення, громадських і промислових об'єктів питною водою, здійснює Держсанепідслужба Закарпатської області. Середній рівень забезпечення населення області водопровідною водою становить 32,2\%. Без міст Ужгород $(98,4 \%)$ та Мукачеве $(86,4 \%)$ цей показник становить $20,7 \%$. У тому числі забезпечення населення райцентрів та міст обласного підпорядкування становить 58,3\%, а сільського населення $-14,5 \%$.

Під наглядом Держсанепідслужби Закарпатської області перебувають 105 джерел централізованого водопостачання (22 комунальні, 39 відомчих, 44 сільські водопроводи) та 4971 джерело децентралізованого водопо- стачання (3 710 колодязів, 634 каптажі, 627 артезіанських свердловин). Із загальної кількості водопроводів 19,0\% не відповідають санітарним нормам і правилам через відсутність зон санітарної охорони (14,2\%), необхідного комплексу очисних споруд (1,9\%) або знезаражувальних установок (7,6\%). Якість питної водопровідної води значною мірою зумовлена характерною в цілому для області ситуацією. Основні проблеми, що стосуються водопостачання населення Закарпатської області:

- зношеність існуючих мереж і обладнання системи водопроводів (м. Ужгород, м. Чоп Ужгородського району, м. Перечин Перечинського району, м. Берегове Берегівського району);

- недостатне фінансування потреб водопровідноканалізаційного господарства;

- періодичні відключення електроенергії від водозаборів, що спричиняє додаткові прориви аварійних трубопроводів унаслідок перепадів тиску в мережі;

- недостатня потужність частини існуючих централізованих водопроводів;

- у сільській місцевості не ведеться будівництво нових водопроводів, практично не проводиться робота 3 очищення громадських колодязів, вигрібних ям і поглинальних колодязів. Велику стурбованість викликає проведення подальшої забудови населених пунктів без вирішення питання водопостачання та каналізування житлових будинків (Semal, 2015).

\section{Заходи, необхідні для поліпшення стану водопостачання населення}

Для реалізації програми «Питна вода Закарпаття» на 2012-2020 роки та виконання невідкладних екологічних заходів необхідні: 
- належне державне фінансування в повному обсязі та розширене інвестування;

- впровадження пріоритетності питного водопостачання перед іншими видами спеціального водокористування;

- впровадження принципів поліпшення екологічного стану водних об'єктів на основі басейнового принципу, на засадах якого повинні бути розроблені та впроваджені водоохоронні програми для окремих населених пунктів;

- посилення державного нагляду та контролю за дотриманням водоохоронного режиму у зонах водозабору та режиму господарювання у прибережних захисних смугах і водоохоронних зонах та винесення їх у натуру;

- ліквідація диспропорції між потужностями водозабірних споруд і каналізаційних очисних споруд;

- будівництво нових i реконструкція існуючих каналізаційно-очисних споруд та мереж водопровідноканалізаційного господарства.

Вирішення проблеми очищення стічних вод і припинення забруднення водних об‘єктів можливе за умови достатньої фінансової підтримки існуючих природоохоронних програм на національному, регіональному та місцевому рівнях. Необхідно забезпечити збільшення фінансування природоохоронних заходів із Державного бюджету.

\section{Висновки}

Закарпатська область - одна з найкраще забезпечених водними ресурсами областей України. Аналізуючи рівень водокористування протягом тривалого часу відмічаємо, що він знижується, як і рівень водовідведення. У той же час проблемою залишається екологічний стан у водоохоронних зонах і прибережних смугах на потоках і річках області. Відсутність конкретних землекористувачів, розформування та розпаювання колективних сільгосппідприємств, віднесення та включення цих земель до адміністративних територій сільських і селищних рад без механізму дієвого контролю - одні з основних причин такого стану водних об'єктів. Можливим шляхом поліпшення ситуації, що склалася, стануть профілактичні водоохоронні заходи, спрямовані на запобігання або обмеження забруднення, засмічення та виснаження вод, а також просвітницька робота серед населення 3 роз'ясненням сучасного стану та можливих наслідків бездумної споживацької діяльності.

\section{Бібліографічні посилання}

Bobyliov, Y.P., Brygadyrenko, V.V., Bulakhov, V.L., Gaichenko, V.A., Gasso, V.Y., Didukh, Y.P., Ivashov, A.V., Kucheriavyi, V.P., Maliovanyi, M.S., Mytsyk, L.P., Pakhomov, O.Y., Tsaryk, I.V., Shabanov, D.A., 2014. Ekologija [Ecology]. Folio, Kharkiv (in Ukrainian).

Chaithanya Sudha, M., Ravichandran, S., Sakthivadivel, R., 2013. Water bodies protection index for assessing the sustainability status of lakes under the influence of urbanization: A case study of south Chennai, India. Environ. Dev. Sustain. 15, 1157-1171.

Di Nardo, A., Di Natale, M., Guida, M., 2013. Water network protection from international contamination by sectorization. Water Resour. Manag. 27, 1837-1850.
Felbaba-Klushyna, L.M., 2009. Oxorona pryrody ekosystemy verxivya basejnu r. Tysy (Zakarpattya) [Nature protection of ecosystems upper basin Tisa (Transcarpathia)] Visn. Uzhgorod. Univ. Ser. Biol. 26, 248-261 (in Ukrainian).

Felbaba-Klushyna, L.M., Nikolajchuk, V.I., 2010. Basejnovyj pidxid do oxorony pryrody Zakarpattya [The basin approach to the nature protection of Transcarpathia]. Material mizhnarodnoyi naukovo-praktychnoyi konferenciyi «Stalyj rozvytok Karpat ta inshykh girskykh regioniv Europy», Uzhgorod. 112-114 (in Ukrainian).

Gerenchuk, K.I., 1981. Pryroda Zakarpatskoyi oblasti [Nature of Transcarpathian region]. Vyshha Shkola, Lviv (in Ukrainian).

Klepov, V.I., 2007. Regulation of environmental-protection water releases in the upper Volga basin as a method of increasing the reliability of water supply in the Moscow Region. Water Resources 34(5), 593-597.

Klimas, A.A., 1995. Impacts of urbanization and protection of water resources in the Vilnius District, Lithuania. Hydrogeol. J. 3(1), 24-35.

Korfali, S.I., Jurdi, M., 2009. Provision of safe domestic water for the promotion and protection of public helth: A case study of the sity of Beirut, Lebanon. Environ. Geochem. Hlth. 31, 283-295.

Kovalchuk, A.A., Nikolajchuk, V.I., Krochko, Y.I., Bojko, M.M., 2001. Prychyny katastrofichnyx pavodkiv u Zakarpatti ta perspektyvy yixnogo unyknennya u majbutnomu [The causes of the disastrous floods in Transcarpathia and their prospects of avoiding in future]. Visn. Uzhgorod. Univ. Ser. Biol. 9, 5-20 (in Ukrainian).

Litskas, V.D., Aschonitis, V.G., Antonopoulos, V.Z., 2010. Water quality in irrigation and drainage networks of Thessaloniki plain in Greece related to land use, water management, and agroecosystem protection. Environ. Monit. Assess. $163,347-359$.

Mishchenko, L.V., 2009. Geoekologichnyi stan komponentiv dovkillya v basejni r. Tysy (Zakarpattya) [Geoecological condition of environmental components in the Tisa basin (Transcarpathia)]. Ekologichna Bezpeka 6, 58-63 (in Ukrainian).

Napier, T.L., Tucker, M., 2001. Use of soil and water protection practices among farmers in the Midwest Watersheds. J. Environ. Manage. 27(2), 269-279.

Nikolajchuk, V.I., 1998. Oxorona dovkillya - najvazhlyvishe zavdannya sogodennya [Environmental protection is the most important task today]. Visn. Uzhgorod. Univ. Ser. Biol. 5, 104-105 (in Ukrainian).

Nikolajchuk, V.I., 2004. Ekologichnyj stan Zakarpattya. Problemy i perspektyvy [Ecological state of Transcarpathia. Problems and prospects]. Medium, Uzhgorod (in Ukrainian).

Nikolajchuk, V.I., 2007. Ekologichni problemy Karpat ta shlyakhy imovirnogo jikh podolannya [Environmental issues of Carpathians and ways to overcome them]. Visn. Uzhgorod. Univ. Ser. Biol. 21, 6-13 (in Ukrainian).

Nikolajchuk, V.I., Grabovskyi, O.V., 2000. Ekologichni problemy Zakarpattya u zvyazku z zabrudnennyam biogeocenoziv vazhkymy metalamy [Environmental problems Transcarpathia due to heavy metals pollution biogeocenosis]. Tezy mizhnarodnoyi konf. «Problemy suchasnoyi ekologiyi». Zaporizhzhya. 30 (in Ukrainian).

Nikolajchuk, V.I., Koval'chuk, A.A., Krochko, Y.I., 2001. Zaklyuchennya naukovoyi komisiyi po vyvchennyu prychyn pavodkiv 4-8 bereznya 2001 roku v Zakarpatskij oblasti ta perspektyvnyx zaxodiv po unyknennyu takyx katastrofichnyx yavyshh u maybutnomu [Conclusion Scientific Commission to study the causes of March 4-8, 2001 in the Transcarpathian region and future measures to avoid such catastrophic events in the future]. Lira, Uzhgorod (in Ukrainian).

Nikolajchuk, V.I., Krochko, Y.I., Krochko, V.Y., 1999. Ekologichni aspekty katastrofichnyx styxijnyx yavyshh v Karpatakh ta shlyakhy yikh poperedzhennya i usunennya [Envi- 
ronmental aspects of catastrophic spontaneous phenomena in the Carpathians and ways of their prevention and treatment]. Materials of mizhnar. konf. «Ekologichni ta socialnoekonomichni aspekty katastrofichnyx styxijnyx yavyshh $\mathrm{u}$ Karpatskomu regioni (poveni, seli, zsuvy)». Raxiv. 249-252 (in Ukrainian).

Nikolajchuk, V.I., Potish, L.A., 2001. Ekologichni osnovy bezperervnogo rozvytku Zakarpattya [Ecological bases of continuous development Transcarpathia]. Materialy regional'noyi nauk.-prakt. konf. «Strategiya stalogo rozvytku Zakarpattya: Ekologo-ekonomichni ta socialni modeli», Uzhgorod. 64-68 (in Ukrainian).

Pop, S.S., 2002. Pryrodni resursy Zakarpattya [Natural resources of Transcarpathia]. Spektral, Uzhgorod (in Ukrainian).

Prikhod'ko, V.E., 2007. Protection of soil and water resources in the United States and Russia. Eurasian Soil Sci. 40(9), 1021-1023.

Semal, V.J., 2014. Dopovid pro stan navkolyshnogo pryrodnogo seredovyshha Zakarpatskoyi oblasti za 2013 rik [Report on Environmental Transcarpathian region by 2013]. Departament ekologiyi ta pryrodnyh resursiv Zakarpatskoyi oblderzhadministraciyi, Uzhgorod. Retrieved from URL www.ecozakarpat.gov.ua/wp-content/uploads/2012/02/Закарпатська-регдоповідь- 2014.pdf (in Ukrainian).

Semal, V.J., 2015. Ekologichnyj pasport Zakarpatskoyi oblasti [Environmental passport Transcarpathian region]. Departament ekologiyi ta pryrodnyx resursiv Zakarpatskoyi oblderzhadministraciyi, Uzhgorod. Retrieved from URL http://ecozakarpat.gov.ua/?page_id=308\# (in Ukrainian).

Shpontak, J.M., 2014. Monitoryng dovkillya v Zakarpatskij oblasti. Informacijno-analitychnyj zvit za 2013 rik [Envi- ronmental Monitoring in Zakarpattia region. InformationAnalytical Report for 2013]. Departament ekologiyi ta pryrodnyx resursiv Zakarpatskoyi oblderzhadministraciyi, Uzhgorod. Retrieved from URL www.ecozakarpat.gov.ua/?page_id=1687 (in Ukrainian).

Stojko, S.M., 2000. Prychyny katastrofichnyx pavodkiv u Zakarpatti ta systema ekologichnyx profilaktychnyx zaxodiv yix poperedzhennya [The causes of the disastrous floods in Transcarpathia and ecological system of preventive measures to prevent them] Ukr. Botan. Zhurn. 57(1), 11-21 (in Ukrainian). Stojko, S.M., 2008. Zberezhennya biologichnogo riznomanittya ta ekologichnogo balansu i pidtrymannya stalogo rozvytku v Karpatakh [Preservation of biological diversity and maintenance of ecological balance and sustainable development in the Carpathians]. Visn. Uzhgorod. Univ. Ser. Biol. 24, 5-10 (in Ukrainian).

Vasylevskyi, G.A., 1973. Vodni bagatstva Karpat [The water wealth of the Carpathians]. Karpaty, Uzhgorod (in Ukrainian).

Walcher, M., Bormann, H., 2015. On the transferability of the concept of drinking water protection zones from EU to Latin American countries. Water Resour. Manag. 29, 1803-1822.

Yakovlev, S.V., Nechaev, A.P., Myasnikova, E.V., Maksimov, A.V., 2002. Integrated water protection strategy based on evaluating the sources of pollution of water bodies. Theoretical Foundations of Chemical Engineering 36(1), 86-92.

Zastavecka, O.V., Zastaveckyi, B.I., 1996. Geografiya Zakarpatskoyi oblasti [Geography of Transcarpathian region]. Pidruchnyky and Posibnyky, Ternopil (in Ukrainian).

Надійшла до редколегї 17.07.2015 